\title{
Overview of genetic markers for hereditary colorectal cancer
}

Rodney J Scott

From Annual Conference on Hereditary Cancers 2012

Szczecin, Poland. 30-31 August 2012

A number of hereditary conditions have been identified that predispose to colorectal cancer. Most inherited forms of colorectal cancer can be placed into two groups, those that are associated with a pre-malignant phenotype (the "polyposis" syndromes) and those do not have a pre-malignant phenotype (generally termed "non-polyposis"). The polyposis syndromes can be further subdivided into two groups; the hamartomatous polyposis syndromes that include Peutz-Jeghers syndrome (PJS), Cowdens' syndrome (PTEN), juvenile polyposis (JPS) and RuvalcabaMyhre-Smith syndrome (RMSS): and the adenomatous polyposis syndromes that include familial adenomatous polyposis, Gardners' syndrome, Oldfields' syndrome Turcot syndrome, Carroli's Disease and MUTYH associated polyposis. The non-polyposis group comprises Lynch syndrome, Muir-Torre's syndrome and Turcot syndrome (there are two forms of Turcot syndrome, one relating to familial adenomatous polyposis and the other to Lynch syndrome).

The genetic basis of the syndromes listed has revealed disease heterogeneity in the non-polyposis group, where all these syndromes are associated with errors in DNA mismatch repair genes (MSH2, MLH1, MSH6 and PMS2). With respect to the adenomatous polyposis syndromes most are associated with mutations in the APC gene, the exception being MUTYH associated polyposis which has been linked to mutations in MUTYH. There are several genes that have been linked to the hamartomatous syndromes, STK11 (LKB1) has been shown to be associated with PJS; PTEN, SMAD4 and BMPR1A with JPS and RMSS and JPS.

Variance in disease expression can not be accounted solely by mutations in the respective gene. Differences between and within families harbouring the same

The Hunter Medical Research Institute; School of Biomedical Sciences and Pharmacy, University of Newcastle; and the Hunter Area Pathology Service, John Hunter Hospital, Newcastle, New South Wales, Australia mutation suggest that other factors are likely to influence disease risk. In the case of Lynch syndrome it is now becoming clear that a series of modifier genes are linked to the age of disease onset and further, the number of modifier risk alleles appears to increase disease severity. Recent evidence suggests that two modifiers of particular interest, located on chromosomes 8 and 11 significantly influence disease onset in MLH1 mutation carriers.

Knowledge about modifier genes and how they impact on disease expression is important for improving personalized patient care, especially in the setting of life-long surveillance and the potential use of significant prophylactic measures to reduce disease risk.

Published: 10 December 2012

doi:10.1186/1897-4287-10-S4-A22

Cite this article as: Scott: Overview of genetic markers for hereditary colorectal cancer. Hereditary Cancer in Clinical Practice 2012 10(Suppl 4): A22.

Submit your next manuscript to BioMed Central and take full advantage of:

- Convenient online submission

- Thorough peer review

- No space constraints or color figure charges

- Immediate publication on acceptance

- Inclusion in PubMed, CAS, Scopus and Google Scholar

- Research which is freely available for redistribution

Submit your manuscript at www.biomedcentral.com/submit
C Biomed Central
C Biomed Central

(c) 2012 Scott; licensee BioMed Central Ltd. This is an Open Access article distributed under the terms of the Creative Commons Attribution License (http://creativecommons.org/licenses/by/2.0), which permits unrestricted use, distribution, and reproduction in any medium, provided the original work is properly cited. 